\section{Paclobutrazol and Reduced Humidity Improve Resistance to Wilting of Micropropagated Grapevine}

\author{
Elaine F. Smith, Ivana Gribaudo ${ }^{1}$, Andrew V. Roberts, and \\ John Mottley \\ Plant Biotechnology Research Unit, Polytechnic of East London, \\ Romford Road, London E15 4LZ United Kingdom
}

Additional index words. in vitro culture, stomata, vitis vinifera

Abstract. Plantlets of Vitis vinifera L. 'Moscato Bianco' were grown in vitro in cellulose plugs (Sorbarods) saturated with a modified Murashige and Skoog rooting medium. Both the inclusion of $0.5-1 \mathrm{mg}$ paclobutrazol/liter in the rooting medium and the use of culture vessels that reduce the relative humidity from $100 \%$ to $94 \%$ improved resistance of plantlets to wilting after transplanting. Maximum benefit was obtained with a combination of paclobutrazol and reduced humidity; it resulted in smaller stomatal apertures, shorter stems, reduced leaf area, and more and thicker roots. Chemical names used: (2RS, 3RS)-1-(4-chlorophenyl)-4,4-dimethyl-2-(1H-1,2,4-triazol-1yl) pentan-3-01 (paclobutrazol).

Grapevine can be rapidly propagated in vitro from shoot tips and axillary buds (Harris and Stevenson, 1982), but micropropagated plantlets are susceptible to rapid desiccation after transfer to soil and require acclimatization. Our aim was to produce hardier plants by modification of Stage III procedures and thus avoid acclimatization with its associated costs of labor and equipment. Three Stage III procedures ameliorated a similar, though less acute, problem in chrysanthemum [Dendrathema grandiflorum (Ramat) Kitamura]. These three were 1) protection of roots by cellulose plugs (Sorbarods) (Roberts and Smith, 1990), 2) inclusion of a triazole growth retardant (paclobutrazol) in the culture medium (Smith et al., 1990a), and 3) the use of culture vessels with reduced humidity (Smith et al., 1990b). In the present invesigation, we rooted plantlets of $V$. vinifera 'Moscato Bianco' in vitro in Sorbarods and studied the effects of paclobutrazol and reduced humidity on their morphology and resistance to wilting.

Stage II culture was on solid medium in glass jars $(300 \mathrm{ml})$ with translucent polypropylene screwcaps (MELI, Brussels, Belgium). The medium consisted of half-strength MS (Murashige and Skoog, 1962) salts, MS vitamins, $30 \mathrm{~g}$ sucrose/liter and $8 \mathrm{~g}$ Difco bacto agar/liter. The $\mathrm{pH}$ was adjusted to 5.6 with $\mathrm{KOH}$ before addition of agar. Stage III

Received for publication 19 Feb. 1991. Accepted for publication 10 Sept. 1991. We thank Baumgartner Papiers SA,. Lausanne, Switzerland, for the gift of Sorbarods and culture vessels and Imperial Chemical Industries Plc, Jealott's Hill Research Station, Bracknell, UK, for the gift of paclobutrazol. The cost of publishing this paper was defrayed in part by the payment of page charges. Under postal regulations, this paper therefore must be hereby marked advertisement solely to indicate this fact.

'Permanent address: Centro Miglioramento Genetico Vite CNR, Via P. Giuria 15, 10126 Torino, Italy. culture vessels were of clear polystyrene with a rectangular base $(155 \times 110 \mathrm{~mm}, 450 \mathrm{ml})$ and contained 60 Sorbarods (Fig. 1). The lid (800 ml) had five holes (20-mm diameter) drilled along both flanks. These were overlaid with a strip of Tyvek Europeel T (Du Pont de Nemours International SA, Geneva) that acted as a tough bacteriological barrier through which water vapor could diffuse. The vessel, with Sorbarods included, was supplied by the manufacturer (Baumgartner Papiers SA, Lausanne, Switzerland) after sterilization by gamma irradiation. Liquid medium (300 ml/vessel) was identical to Stage II medium except for the exclusion of agar and the addition, in some treatments, of 0.5 $1.0 \mathrm{mg}$ paclobutrazol/liter (analytical grade; ICI, Bracknell, U.K.). The vessels were maintained at $94 \%$ relative humidity $(\mathrm{RH})$, but in some treatments, the membrane was covered by adhesive tape to establish $100 \%$ $\mathrm{RH}$. The relative humidity in the culture vessels was measured with an HL 240 D humidity meter (Lee-Dickens, Kettering, U.K.).

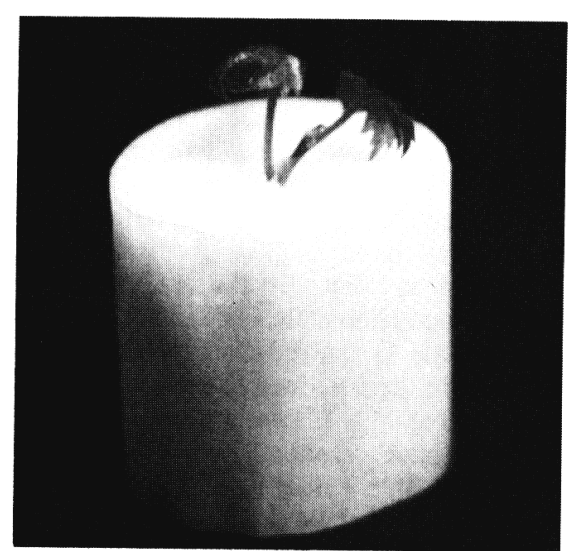

Fig. 1. Sorbarod, consisting of a cylinder (20 $\mathrm{mm}$ long $\times 18 \mathrm{~mm}$ diameter) of cold-crimped cellulose wrapped in cellulose paper, with shoot tip inserted.
The barrel of probe was sealed into a circular hole cut in the lid and held in a central position. All cultures were maintained at $23 \mathrm{C}$ in a $16-\mathrm{h}$ photoperiod provided by cool-white fluorescent lights (Thorn, London) giving $57 \mu \mathrm{mol} \cdot \mathrm{m}^{-2} \cdot \mathrm{s}^{-1}$ at the plant surface. Shoot tips $(5 \mathrm{~mm})$ were inserted into the Sorbarods (Fig. 1) to initiate Stage III culture. Plantlets were assigned numbers according to their position in the culture vessels and taken randomly for wilting tests and measurements after 4 weeks.

Plantlets (25 per treatment) were transferred, rooted in Sorbarods, to water-saturated potting compost in plant pots $(250 \mathrm{ml})$ and assessed for wilting. They were maintained at $100 \% \mathrm{RH}$ for $0.5 \mathrm{~h}$, then exposed, in a randomized matrix, to $62 \% \pm 2 \% \mathrm{RH}$ at $30 \pm 1 \mathrm{C}$ under continuous lighting supplied by warm-white fluorescent tubes giving $318 \mu \mathrm{mol} \cdot \mathrm{m}^{-2} \cdot \mathrm{s}^{-1}$ at the plant level. Wilting was scored individually on a scale of 0 (turgid) to 4 (completely wilted) at intervals for $6 \mathrm{~h}$ and mean wilting scores were calculated for each treatment.

Stomatal apertures were assessed after exposure for $18 \mathrm{~h}$ to stimuli that induce closure in vivo; that is, a dry atmosphere $(20 \% \mathrm{RH}$ at $23 \mathrm{C}$ ) and darkness. Stomatal impressions were then made by applying nail varnish to the abaxial surface of leaves. The apertures of 20 stomata on the second youngest expanded leaf on each of five plantlets per treatment were measured with a microscope equipped with a micrometer eyepiece.

Plantlets cultured without paclobutrazol at $100 \% \mathrm{RH}$ wilted severely when transferred to $62.5 \% \mathrm{RH}$ for $6 \mathrm{~h}$ and were subsequently unable to regain turgor. Plantlets treated with $0.5-1.0 \mathrm{mg}$ paclobutrazol/liter at $100 \% \mathrm{RH}$ and plantlets cultured without paclobutrazol at $94 \% \mathrm{RH}$ wilted less and subsequently regained full turgor when re-

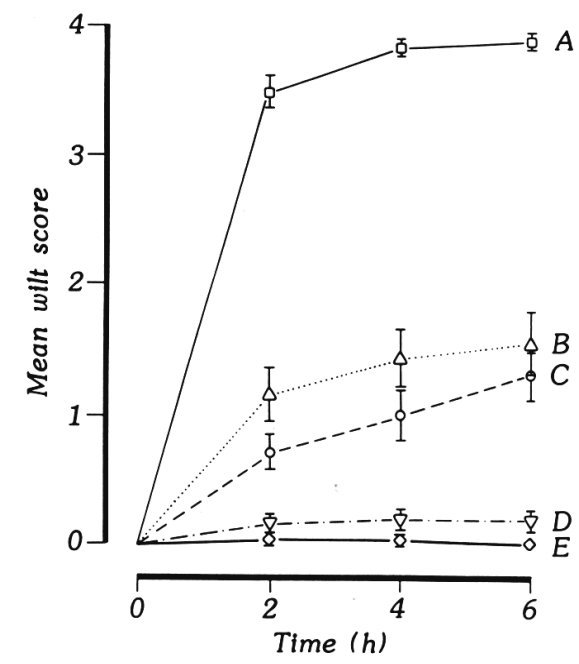

Fig. 2. Mean wilt scores in relation to time following exposure to $62 \% \pm 2 \% \mathrm{RH}$ at $30 \pm$ 1C. Bar linesindicate SE. Treatments : $0 \mathrm{mg}$ paclobutrazol/liter, $100 \% \mathrm{RH}$ (A); $0.5 \mathrm{mg}$ paclobutrazol/liter, $100 \%$ RH (B); 1 mg paclobutrazol/liter, $100 \% \mathrm{RH}$ (C); 0 mg paclobutrazol/ liter, 94\% RH (D); $1 \mathrm{mg}$ paclobutrazol/liter, 94\% RH (E). 
Table 1. The effect of paclobutrazol and relative humidity $(\mathrm{RH})$ on various morphological characters of 'Moscato Bianco' plantlets after 4 weeks in Stage III culture. The means are based on 2.5 plantlets per treatment.

\begin{tabular}{|c|c|c|c|c|c|c|c|}
\hline \multirow[b]{3}{*}{ Plant organ } & \multicolumn{4}{|c|}{ Relative humidity (\%) } & & & \\
\hline & \multirow{2}{*}{$\begin{array}{c}100 \\
0\end{array}$} & \multicolumn{2}{|c|}{$\begin{array}{cc}100 & 94 \\
\text { Paclobutrazol }\left(\mathrm{mg} \cdot \text { liter }^{-1}\right)\end{array}$} & \multirow{2}{*}{$\begin{array}{c}94 \\
1 \\
\end{array}$} & \multicolumn{3}{|c|}{ Two-way analysis of variance } \\
\hline & & 1 & 0 & & Factor & F value & Probability \\
\hline \multicolumn{8}{|l|}{$\overline{\text { Stems }}$} \\
\hline Length (mm) & 34 & 11 & 21 & 10 & $\begin{array}{l}\text { RH } \\
\text { Paclobutrazol } \\
\text { Interaction }\end{array}$ & $\begin{array}{c}18.74 \\
201.66 \\
17.29\end{array}$ & $\begin{array}{l}<0.01 \\
<0.01 \\
<0.01\end{array}$ \\
\hline \multicolumn{8}{|l|}{ Expanded leaves } \\
\hline No./plant & 3.6 & 3.1 & 2.8 & 2.0 & $\begin{array}{l}\text { RH } \\
\text { Paclobutrazol } \\
\text { Interaction }\end{array}$ & $\begin{array}{r}60.53 \\
29.98 \\
2.30\end{array}$ & $\begin{array}{l}<0.01 \\
<0.01 \\
>0.05\end{array}$ \\
\hline Area/leaf $\left(\mathrm{mm}^{2}\right)$ & 104 & 62 & 176 & 85 & $\begin{array}{l}\text { RH } \\
\text { Paclobutrazol } \\
\text { Interaction }\end{array}$ & $\begin{array}{r}12.98 \\
28.29 \\
0.86\end{array}$ & $\begin{array}{l}>0.01 \\
<0.01 \\
>0.05\end{array}$ \\
\hline Area/plant $\left(\mathrm{mm}^{2}\right)$ & 380 & 192 & 519 & . 175 & $\begin{array}{l}\text { RH } \\
\text { Paclobutrazol } \\
\text { Interaction }\end{array}$ & $\begin{array}{r}1.56 \\
30.07 \\
2.57\end{array}$ & $\begin{array}{l}>0.05 \\
<0.01 \\
>0.05\end{array}$ \\
\hline \multicolumn{8}{|l|}{ Roots } \\
\hline No./plant & 4.6 & 8.2 & 4.5 & 5.9 & $\begin{array}{l}\text { RH } \\
\text { Paclobutrazol } \\
\text { Interaction }\end{array}$ & $\begin{array}{r}4.48 \\
22.37 \\
3.57\end{array}$ & $\begin{array}{l}<0.01 \\
<0.01 \\
>0.05\end{array}$ \\
\hline Avg diam (mm) & 0.7 & 1.0 & 0.7 & 1.1 & $\begin{array}{l}\text { RH } \\
\text { Paclobutrazol } \\
\text { Interaction }\end{array}$ & $\begin{array}{c}18.35 \\
278.00 \\
0.248\end{array}$ & $\begin{array}{l}<0.01 \\
<0.01 \\
>0.05\end{array}$ \\
\hline
\end{tabular}

Transformations of data to achieve normality and homoscedasticity: log for stem length and leaf area; square-root for leaf number and root number.

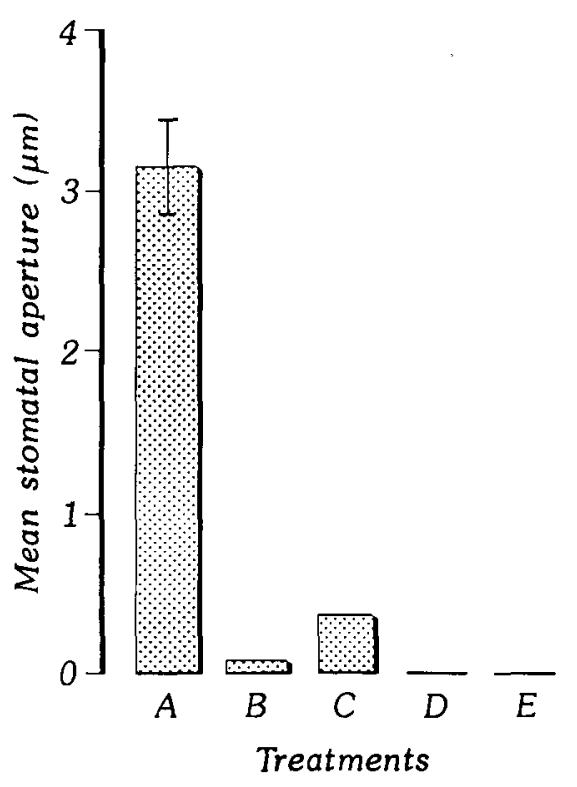

Fig. 3. Mean stomata1 apertures of the second youngest leaf per shoot following exposure to $20 \% \mathrm{RH}$ at $23 \mathrm{C}$ for $18 \mathrm{~h}$ in darkness. Means are based on 20 stomata on each of five leaves. Bar line indicates SE. Treatments : $0 \mathrm{mg}$ paclobutrazol/liter, $100 \%$ RH (A); 0.5 m.g paclobutrazol/liter, $100 \% \mathrm{RH}(\mathrm{B}) ; 1 \mathrm{mg}$ paclobutrazol/ liter, $100 \% \mathrm{RH}$ (C); 0 mg paclobutrazol/liter, 94\% RH (D); $1 \mathrm{mg}$ paclobutrazol/liter, 94\% RH (E).

turned to a humid atmosphere. Plantlets treated with $1 \mathrm{mg}$ paclobutrazol/liter at $94 \%$ RH showed negligible wilting (Fig. 2). Smaller stomatal apertures in water-stressed plantlets treated with paclobutrazol and reduced humidity, separately and in combination (Fig. 3), apparently minimized water loss. Reductions in leaf area per plant in response to paclobutrazol probably reduced transpiration (Table 1). Thicker roots and shorter stems induced by paclobutrazol and reduced humidity, and the greater number of roots induced by paclobutrazol (Table 1) may have facilitated replacement of the water lost by the leaves.

Increased resistance to wilting associated with improved stomatal responses, reduction in stem length, leaf number and leaf area, and increases in root diameter have also been observed in response to paclobutrazol in chrysanthemum cultured in vitro (Smith et al., 1990a). Rooting was also promoted by paclobutrazol in Plectranthus australtis R. Br. and Phaseolus vulgaris L. grown in vivo (Davis et al., 1985) and by another growth retardant, ancymidol, in Asparagus officinalis L. cultured in vitro (Chin, 1982). Improved stomatal responses in plantlets grown in vitro at reduced humidity have also been reported in chrysanthemum (Short et al., 1987; Smith et al., 1990b; Wardle et al., 1983) and carnation (Dianthus calyophyllus L.) (Ziv et al., 1987). We postulate that improved stomatal behavior under reduced humidity may have resulted from increased solute concentrations in the epidermis following evaporation at the leaf surface. Shorter stems (Table 1) and red discolorations were observed in the first-formed leaves of plantlets grown at $94 \% \mathrm{RH}$ without paclobutrazol and may have resulted from water stress. There was little evidence of such stress in plantlets grown at $94 \% \mathrm{RH}$ with $1 \mathrm{mg}$ paclobutrazol/liter, which indicates that paclobutrazol ameliorated this problem. This view is supported by the highly significant interaction between relative humidity and paclobutrazol on stem length (Table 1). It seems, therefore, that maximum benefit is to be gained by exploiting the complementary effects of relative humidity and paclobutrazol rather than by increasing the concentration of paclobutrazol beyond $1 \mathrm{mg} \cdot$ liter $^{-1}$ or further reducing humidity.

After transfer to soil in temperate greenhouse conditions, without acclimatization, plantlets of grapevine that are rooted in Sorbarods and treated with paclobutrazol at 1 $\mathrm{mg} \cdot \mathrm{liter}^{-1}$ at $94 \% \mathrm{RH}$ rapidly regain any lost turgor. Leaves that were formed in vitro persist for a further 3 to 4 weeks.

\section{Literature Cited}

Chin, C.-K. 1982. Promotion of shoot and root formation in asparagus in vitro by ancymidol. HortScience 17:590-591.

Davis, T.D., N. Sankhla, R.H. Walser, and A. Upadhyaya. 1985. Promotion of adventitious root formation on cuttings by paclobutrazol. HortScience 20:883-884.

Harris, R.E. and J.H. Stevenson. 1982. In vitro propagation of Vitis. Vitis 21:22-32.

Murashige, T. and F. Skoog. 1962. A revised medium for rapid growth and bioassays with tobacco cultures. Physiol. Plant. 15:473-497.

Roberts, A.V. and E.F. Smith. 1990. The preparation in vitro of chrysanthemum for transplantation to soil. 1. Protection of roots by cellulose plugs. Plant Cell, Tissue Organ Cult. 21:129-139.

Short, K.C., J. Warburton, and A.V. Roberts. 1987. In vitro hardening of cultured cauliflower and chrysanthemum plantlets to humidity. Acta Hort. 212:329-334

Smith, E.F., A.V. Roberts, and J. Mottley. 1990a. The preparation in vitro of chrysanthemum for transplantation to soil. 2. Improved resistance to desiccation conferred by paclobutrazol. Plant Cell, Tissue Organ Cult. 21:133-140.

Smith E.F., A.V. Roberts, and J. Mottley. 1990b.

The preparation in vitro of chrysanthemum for 
transplantation to soil. 3. Improved resistance to desiccation conferred by reduced humidity.

Plant Cell, Tissue Organ Cult. 21:141-145.

Wardle, K., E.B. Dobbs, and K.C. Short. 1983.
In vitro acclimatization of aseptically cultured plantlets to humidity. J. Amer. Soc. Hort. Sci. 108:368-389

Ziv, M., A. Schwartz, and D. Fleminger. 1987.
Malfunctioning stomata in vitreous leaves of carnation (Dianthus caryophyllus) plants propagated in vitro; implications for hardening. Plant Sci. 52:127-134. 